\title{
Кубекин Д.М., Кривошеева Е.И. \\ Спецификация перевода текстов сельскохозяйственной сферы с японского на русский язык в рамках реализации проектов ТОР с японским участием
}

Тихоокеанский государственньй университет (Россия, Хабаровск)

doi: $10.18411 / \mathrm{j}-08-2021-95$

\section{Аннотация}

В статье рассматриваются характерные особенности научно-технических текстов в сфере сельского хозяйства на японском языке. Сотрудничество в указанной области реализуется Россией и Японией в совместных сельскохозяйственных проектах на территориях опережающего развития (ТОР). В работе выявляются и анализируются трудности технической описательной и графической документации по теме производства минеральных удобрений на японском языке и предлагаются переводческие решения для адекватной передачи информации на русский язык.

Ключевые слова: технический перевод, японский язык, Япония, Россия, сотрудничество, сельское хозяйство, удобрения, ТОР.

\section{Abstract}

The article discusses the characteristic features of scientific and technical texts in the field of agriculture in Japanese. Cooperation in this area is actively developing between Russia and Japan, which is reflected in agricultural projects in priority development areas. This paper identifies the difficulties of translating the texts of the technical industry in terms of the production of mineral fertilizers and proposes translation solutions for the adequate transfer of information into Russian.

Keywords: technical translation, Japanese language, Japan, Russia, cooperation, agriculture, PDA.

Последние 5 лет Россия и Япония ведут тесное сотрудничество в разных сферах экономической деятельности в контексте плана из 8-ми пунктов, который принят за основу двустороннего взаимодействия в 2018 г. Совместное освоение территорий опережающего развития (ТОР) на Дальнем Востоке России является важным пунктом этого плана в рамках установленных договоренностей между лидерами двух государств.

В течение последних четырех лет доля поставок сельскохозяйственного сырья из России в Японию держится на отметке $23 \%$ от общей доли экспорта, и согласно позиции Минсельхоза РФ, сделанного в конце 2020 года, Россия заинтересована в диверсификации сельскохозяйственного сырья, экспортируемого в Японию, а также в развитии сотрудничества с Японией в сфере сельского хозяйства в целом [3]. Одним из компонентов реализации такого сотрудничества является либо закупка удобрений в Японии, либо производство японских удобрений российскими химическими предприятиями.

Рассмотрев и проанализировав почвенные карты Японии, а также Приморского и Хабаровского краёв, был сделан вывод, что общим распространённым типами почв и в Японии, и в России являются бурые и аллювиальные почвы, поэтому японские удобрения могут быть использованы и на российских почвах. Можно так же отметить, что сера, как один из важнейших компонентов исследуемых удобрений, является дефицитным элементом в подобных почвах, особенно в аллювиальных, в которых происходит постоянное вымывание микроэлементов.

В данной работе предпринимается попытка выявления сложностей перевода научно-технических терминов в текстах сферы сельского хозяйства с японского на 
русский язык. Материалом послужили статьи об удобрениях с серным покрытием с сайта японского производителя Toyoda Yuuki Hiryou Koubou [4], а также статьи, посвященные различным типам почв в японской классификации из японских источников.

При переводе материалов удалось выявить большой спектр сложностей, которые можно разделить на две основные группы: лингвистические и экстралингвистические.

К лингвистическим сложностям относится:

- наличие терминов из разных отраслей науки: биология, химия и т.д.;

- многокомпонентные терминологические сочетания;

- имплицитность.

Рассмотрим каждую из категорий подробно.

В процессе перевода в тексте были обнаружены термины из различных областей науки, например, химии:

硫黄も微生物により分解され、肥料成分の溶出が更に進行する[4] - Cepa также разлагается микроорганизмами, прочесс элюирования продолжается.

土壤に硫黄を施用すると土壤の $\mathrm{p} \mathrm{H}$ 酸性化することがしられていますが [5]

Известно, что внесение серы в почву приводит кеё подкислению и повышению рН.

Из многокомпонентных терминов были выделены следующие слова. 硫黄被覆肥料 - состоит из двух терминов «серное покрытие»и «удобрение»и на русский язык мы его передадим, как «удобрение с серным покрытием»; 石灰資材 состоит из терминов «известь» и «материал», однако эквивалентным переводом будет «известковые удобрения»; 沖積性土壤 - «аллювиальный грунт»; 構成元素 «составные элементыл».

В процессе перевода научно-технических текстов переводчик может встретиться с логическими ошибками, имплицитностью и громоздкостью синтаксического оформления, что вызывает сложность при передаче на русский язык [1]. Например, 一般に肥料成分の吸収比率は、窒素 $(\mathrm{N})$ : りん酸(P2O5): 加里 $(\mathrm{K} 2 \mathrm{O})$ : 硫黄 $(\mathrm{S})=$ $10: 4: 6: 3$

\section{と言われており、日本国内では硫黄が肥料成分として認可されていないためあまり} その必要性が認識されていませんが、その吸収量は非常に多く、作物によってはり

ん酸以上に必要とされています。Следует отметить громоздкость данного предложения - 127 символов. В связи с этим было принято решение разделить его на более короткие составляющие. В тексте упущено описание важности фосфорной кислоты, и переводчику необходимо обращаться к фоновым знаниям, чтобы понять смысл данного предложения. Так, фосфорная кислота нужна растениям для фотосинтеза. Переводчику следует учесть данное упущение оригинала, и перевести с уточнением. Также следует обратить внимание на логическую ошибку и недосказанность оригинала, которая могла бы привести к неправильному переводу. Сера запрещена в Японии в качестве основного элемента удобрений, однако в качестве второстепенного элемента, в данном случае покрытия, она разрешена. В оригинальном тексте данный нюанс не остался на разъяснённым.

Из экстралингвистических сложностей были выделены:

- различия в классификации почвоведения Японии и России;

- контекст и необходимость наличия фоновых знаний.

Так, термин 停滞水成士 - согласно японским источникам, - это почва плоскогорий, холмов и гор, которая подвержена влиянию застойной воды или грунтовых вод [6]. В российском почвоведении наиболее подходящий термин глеевые почвы. В японской классификации глеевые почвы делятся на два типа 停滞水グライ土дословно застойные глеевые и псевдоглеевые - 疑似グライ土. В российской классификации данный тип почв представлен куда большими вариациями: глеезёмы, торфяно-глеезёмы, гумусово-глеевые, перегнойно-глеевые и т.д. [7]. Важным 
условием в переводе таких терминов является адресат. В случае перевода научнопопулярной статьи в журнале, будет достаточно термина «глеевые почвы». В случае же профессиональной литературы необходимо переводить как можно точнее, и выяснить тип почвы, которая имеется в виду.

Ещё один пример подобного несоответствия: 赤黄色土 - несмотря на то, что в российском почвоведении действительно есть термин красно-жёлтая почва, соответствующая дословному переводу японского термина, этот тип почвы попадает в подраздел ферраллитных почв, поэтому верный перевод: ферраллитные красно-желтые почвы.

Отдельно можно выделить графические материалы, перевод которых обладает своими особенностями. Так, из-за максимальной сжатости передаваемой информации на схемах и графиках может присутствовать аббревиация и сокращения [2], кроме того, в некоторых случаях, из-за различий между японским и русским языком, могут возникнуть сложности технического характера, когда перевод термина не подходит для использования в схеме из-за большого объёма, в таком случае необходимо найти наиболее ёмкий эквивалент, а если такого не имеется, прибегнуть к техническому решению проблемы, например, откорректировать место надписи, сохранив читаемость схемы или графика.

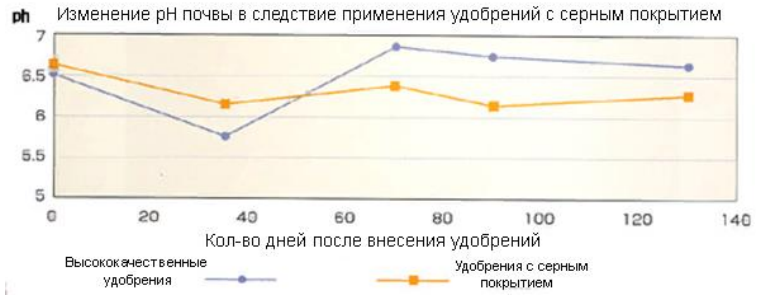

Puc.1

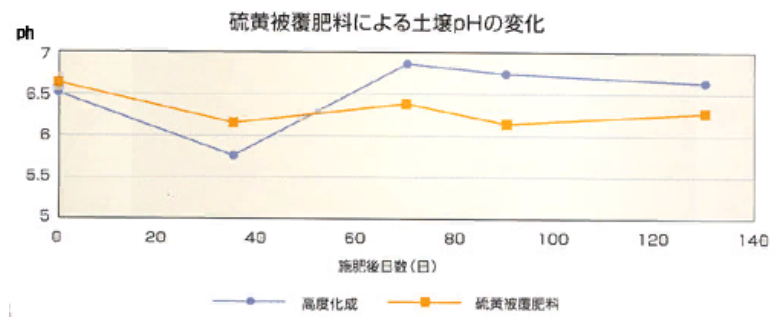

Puc. 2

На Рис.1 и Рис.2 представлен пример переведённого графика изменения кислотности почвы после внесения удобрений, описанных в статье, по сравнению с другими высококачественными удобрениями.

Таким образом, можно сделать вывод о том, что в сфере сельского хозяйства при переводе текстов отраслевой переводчик может столкнуться с такими проблемами, как: имплицитность, синтаксическая громоздкость, логические ошибки, несмотря на то, что научно-технический стиль подразумевает лаконичность и точность. Помимо этого, различия в терминологии в отрасли почвоведения между русским и японским языком также являются серьёзным препятствием при переводе.

1. Климзо, Б.Н. Ремесло технического переводчика / Б.Н. Климзо. - 2-е изд., стер. - М.: Р. Валент, 2006. - С. 55 - 90. - ISBN 5-93439-194-1.

2. Кутафьева Н.В. Японский язык Особенности научно-технического стиля-2005.

3. Поощрение диверсификации промышленной структуры России и повышение производительности [Электронный ресурс]: Режим доступа https://www.vladivostok.ru.emb-japan.go.jp/rus/bilaterialrelations/index.html (дата обращения 15.04.21).

4. 緩効性肥料被覆窒素質肥料＼cjkstart硫黄コーティング肥料（リニア）[Электронный ресурс]: Режим доступа http://www.toyodayuki.co.jp/genryo/genryo-24.htm (дата обращения 15.04.21).

5. 超緩効性肥料目地ロール尿素重合肥料 ミクレア 360 日[Электронный доступа http://www.toyodayuki.co.jp/genryo/genryo-23.htm (дата обращения 15.04.21).

6. 停帯水成土 [Электронный ресурс]: Режим доступа https://soil-inventory.dc.affrc.go.jp/explain/H.html (дата обращения 15.04.21).

7. Отдел глеевых почв [Электронный ресурс]: Режим доступа http://soils.narod.ru/interactive/gl/Gl.html (дата обращения 15.04.21). 